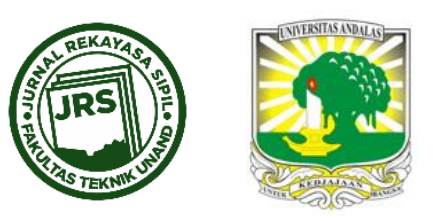

\title{
PENGARUH PERKUATAN PELAT BESI TERHADAP KEKUATAN SAMBUNGAN KAYU TAKIKAN LURUS
}

\author{
AGUSTINA HAYATUNNUFUS ${ }^{1}$, NARESWORO NUGROHO ${ }^{2}$, \\ FENGKY SATRIA YORESTA ${ }^{3}$ \\ ${ }^{1}$ Alumni Institut Pertanian Bogor, Kampus IPB Dramaga, Bogor (agustina9456@gmail.com) \\ ${ }^{2}$ Institut Pertanian Bogor, Kampus IPB Dramaga,Bogor (nareworo@yahoo.com) \\ ${ }^{3}$ Institut Pertanian Bogor, Kampus IPB Dramaga, Bogor(凶syfengky@gmail.com)
}

Naskah diterima : 1 Februari 2018. Disetujui: 12 April 2018. Diterbitkan : 1 Juli 2018

\begin{abstract}
ABSTRAK
Sambungan kayu pada konstruksi merupakan faktor kritis dalam desain struktur karena kekuatan strukturnya ditentukan oleh kekuatan sambungan. Tujuan penelitian ini adalah untuk mengkaji pengaruh pelat besi terhadap kekuatan sambungan kayu menggunakan sambungan takikan lurus. Pada penelitian ini, material sambungan yang digunakan yaitu kayu Kamper (Dryobalanops sp) dan kayu Mersawa (Anisoptera sp) menggunakan alat pengencang paku dengan perkuatan pelat besi dengan ukuran panjang masing-masing $5 \mathrm{~cm}, 10 \mathrm{~cm}$, dan $15 \mathrm{~cm}$. Pengujian sifat fisis, sifat mekanis, dan kapasitas sambungan kayu dilakukan berdasarkan standar ASTM D143-94, BS 3731957, ASTM 1575-03, dan SNI 7973: 2013. Hasil dari penelitian ini menunjukkan bahwa penggunaan tambahan pelat besi pada sambungan kayu takikan lurus mampu meningkatkan kapasitas tahanan sambungan tersebut. Hal ini dibuktikan dari nilai momen tahanan aktual sambungan dengan pelat besi yang lebih tinggi dari nilai momen acuan dan momen tahanan sambungan tanpa pelat besi baik pada kayu Kamper maupun Mersawa.
\end{abstract}

Kata kunci : pelat besi, sambungan kayu, kapasitas, takikan lurus

\section{PENDAhUluan}

Kayu sebagai salah satu bahan konstruksi banyak digunakan di Indonesia, antara lain untuk keperluan bangunan gedung, rumah tinggal, jembatan, bantalan kereta api dan lain-lainnya. Pada struktur yang bahan utamanya kayu, sambungan atau buhul muncul karena alasan geometrik (bentuk struktur) dan keterbatasan ukuran panjang batang kayu yang tersedia. Sambungan merupakan bagian yang paling lemah sehingga banyak kegagalan atau kerusakan struktur sering disebabkan oleh gagalnya sambungan (Awaludin 2005) dan menurut Porteous et al. (2007), sambungan merupakan faktor kritis dalam desain struktur dimana kekuatan strukturnya umumnya ditentukan oleh kekuatan sambungan. Oleh sebab 
itu, maka batang-batang kayu perlu disambung untuk bisa mencapai bentang struktur yang dikehendaki.

Salah satu cara untuk menanggulangi masalah keterbatasan panjang kayu adalah dengan disambungnya batang-batang kayu sehingga dapat mencapai bentang struktur yang dikehendaki. Perlu adanya perencanaan sambungan meliputi pemilihan alat sambung dan detail sambungan serta perkuatan pada sambungan kayu sehingga dapat meminimalisir terjadinya kerusakan.

Tikno (2008) mengemukakan bahwa sambungan kayu baik pada furniture atau meubel mutlak ada agar strukturnya kuat dan kaku. Pada pembuatan sambungan kayu ada banyak sekali teknik sambungan kayu yang digunakan baik itu sambungan pada papan maupun sambungan yang bersifat konstruksi. Salah satu jenis alat sambung yang umum dipakai adalah sambungan siku atau sambungan sudut. Sambungan siku dilakukan dengan cara memadukan dua buah kayu untuk membentuk sudut tertentu,umumnya sebesar 90 derajat. Salah satu teknik untuk membuat sambungan siku ini adalah sambungan takikan lurus atau dikenal sebagai half lap joint. Pada penelitian ini dilakukan untuk melihat respon yang terjadi pada sambungan kayu menggunakan jenis sambungan takikan lurus (half lap joints) dengan perkuatan pelat besi. Tujuan penelitian ini adalah untuk mengkaji pengaruh perkuatan pelat besi terhadap kekuatan sambungan kayu menggunakan sambungan takikan lurus.

\section{TINJAUAN PUSTAKA}

Kayu merupakan material yang diperoleh secara alami dari pohon. Kayu bersifat renewable yaitu sumbernya menjamin ketersediaan sepanjang masa selama pengelolaan sumber daya alamnya dilakukan secara lestari (Surjokusumo et al. 2003). Kayu juga dapat didaur ulang secara sempurna dan $100 \%$ dapat terurai di alam (bio-degradable). Dengan demikian, kayu menjadi satu-satunya bahan struktur saat ini yang ramah lingkungan (Awaludin 2005). Kayu juga merupakan suatu bahan konstruksi yang didapatkan dari tumbuhan di alam. Oleh karena itu, kayu tidak hanya merupakan salah satu bahan konstruksi pertama di dalam sejarah umat manusia, tetapi mungkin juga menjadi yang terakhir.

Sebagai salah satu bahan konstruksi pertama, teknik penggunaan kayu sebagai bahan konstruksi pada jaman yang lampau didasarkan atas pengalaman dan intuisi. Kayu mempunyai kekuatan yang tinggi dan berat yang rendah, mempunyai daya penahan yang tinggi terhadap pengaruh kimia dan listrik, mudah dikerjakan, relatif murah, mudah diganti, dan bisa didapat dalam waktu yang singkat (Yap 1964). Kayu merupakan bahan bangunan yang sifatnya sangat variatif menurut jenis, zona penggergajian (gubal dan teras) sertaarah irisan (radial, tangensial dan longitudinal). Oleh karena itu dalam aplikasi struktur sangat diperlukan data mengenai sifat fisik dan mekanik setiap jenis kayu (Somayaji 1995).

Kayu kamper (Dryopbalanops sp) terdiri dari lima spesies diantaranya adalah D.aromatica, D.fusca, D.lanceolata, D.oocarpa, dan D. rappa. Kayu kamper digolongkan dalam kayu dengan kelas kuat II - III serta kelas awet II - III dengan berat jenis 0,62 - 0,91 tergantung spesiesnya (PKKI NI-5 1961). Secara visual terlihat arah serat kayu terpadu dengan bau kamper yang tajam dan dapat dibedakan atau digolongkan menurut tekstur dan warna (Martawijaya et al. 1977).

Kayu mersawa (Anisoptera sp) terdiri dari tiga jenis penting diantaranya $A$. costata, $A$. grossivenia, A. marginata. Kegunaan kayumersawa yaitu untuk bangunan ringan di bawah atap seperti balok, kaso, reng, dan papan, dijadikan sebagai kano,venir luar dan dalam untuk 
kayu lapis, mebel, papan perahu, dan lantai (Onrizal 2007). Kayu mersawa digolong dalam kayu dengan kelas kuat II-III serta kelas awet IV dengan berat jenis 0,49-0,85 tergantung spesiesnya (Yap 1964).

Dalam perkembangannya, struktur kayu banyak digunakan sebagai alternatif dalam perencanaan pekerjaan-pekerjaan sipil, diantaranya adalah rangka kuda-kuda, rangka dan gelagar jembatan, struktur perancah, kolom, dan balok lantai bangunan. Disamping itu, dalam penggunaannya dari struktur rangka batang dapat dilakukan dengan adanya sambungan untuk memperkuat struktur tersebut. Menurut Awaludin (2005) menyatakan bahwa pada konstruksi kayu sering diperlukan sambungan yang berfungsi untuk memperpanjang batang kayu (overlapping connection) atau menggabungkan beberapa batang kayu pada satu buhul atau joint.

Berdasarkan interaksi gaya-gaya yang terjadi pada sambungan, alat sambung mekanik dapat dikelompokkan menjadi dua kelompok. Kelompok pertama adalah kelompok alat sambung yang kekuatan sambungannya berasal dari interaksi antara kuat lentur alat sambung dengan kuat desak atau kuat geser kayu. Kelompok kedua adalah kelompok alat sambung yang kekuatan sambungannya ditentukan oleh luas bidang dukung kayu yang disambungnya. Alat sambung paku dan baut termasuk pada kelompok alat sambung jenis pertama. Berhubungan dalam hal ini, sambungan takikan lurus (half lap joints) diperkuat dengan aksen sambungan paku. Half lap joints merupakan sambungan siku yang menggunakan baguan ketebalan papan dengan cara memotong ketebalan papan masing-masing setengahnya, kemudian papan menjadi satu. Setelah itu papan dipaku atau dilem (Tikno 2008). Sambungan ini dapat digunakan sepanjang balok dipikul secara merata dan tidak menerima gaya tarik maupun momen lentur, misalnya balok tembok. Pada sambungan ini takiknya (coakan) 1/2 tebal kayu.

Kegagalan struktur pada sambungan dapat berakibat fatal yakni runtuh atau rusaknya beberapa komponen (Kurniady 2007). Pencegahan yang dilakukan agar tidak terjadi kegagalan struktur pada sambungan yaitu diberikan perkuatan pelat besi pada struktur rangka batang. Perkuatan yang cukup sering dijumpai adalah menggunakan pelat baja atau pelat besi. Pelat tersebut dipasang karena dimensi penampang kayu ternyata tidak cukup untul memikul beban yang bekerja. Pertimbangan lain yang lebih terutama sekali karena tidak mungkin lagi untuk mengganti atau memperbesar penampang kayu yang ada. Pertimbangan tersebut cukup rasional, mengingat bahwa dalam dimensi yang sama pelat akan mempunyai kemampuan memikul beban yang lebih jauh besar daripada kayu. Dengan menggunakan perkuatan pelat ini penambahan dimensi menjadi tidak begitu besar sehingga lebih praktis (Danasasmita et al. 2004).

Besi adalah logam yang paling luas dan paling banyak penggunaannya. Hal tersebut disebabkan karena besi relatif melimpah di berbagai penjuru dunia, pengolahan besi relatif murah dan mudah, dan sifat - sifat besi yang mudah dimodifikasi. Pelat besi merupakan suatu unsur besi berupa pelat baik pelat lembaran maupun pelat strip dengan tebal antara3 $\mathrm{mm}$ sampai dengan $60 \mathrm{~mm}$. Pelat lembaran terdapat dengan lebar antara $150 \mathrm{~mm}$ sampai dengan $4300 \mathrm{~mm}$ dengan panjang 3 sampai dengan 6 meter. Sedangakan, pelat strip biasanya dengan lebar $600 \mathrm{~mm}$ dengan panjang 3 sampai dengan 6 meter. Permukaan pelat besi ada yang polos dan ada yang bermotif dalam berbagai bentuk motif. Namun untuk keperluan konstruksi pada umumnyadigunakan baja pelat yang polos rata dengan lebar dapat dipotong sendiri sesuai dengan kebutuhan (Supriatna 2011). 


\section{METODE PENELITIAN}

Balok kayu Kamper dan kayu Mersawa dipotong dengan dimensi batang kayu masingmasing penampang berukuran $(4 \times 10 \times 50) \mathrm{cm}^{3}$ untuk batang horisontal dan batang vertikal. Pembuatan sambungan yang dilakukan menggunakan teknik sambungan takikan lurus seperti yang disajikan pada Gambar 1. Material sambungan takikan lurus menggunakan kayu Kamper dan Mersawa kemudian dipotong dengan ketebalan papan masing-masing menjadi setengahnya dengan ukuran $2 \mathrm{~cm}$, sedangkan lebar dan panjangnya masing-masing berukuran $10 \mathrm{~cm}$ dan $50 \mathrm{~cm}$. kemudian papan ditumpuk menjadi satu. Setelah itu papan diperkuat menggunakan paku sebanyak 8 buah paku. Jarak tepi paku sepanjang $2 \mathrm{~cm}$ dan jarak antar paku sepanjang $3 \mathrm{~cm}$.

Pelat besi berbentuk lembaran dipotong dengan ukuran $(5 \times 4 \times 0.3) \mathrm{cm}^{3},(10 \times 4 \times 0.3) \mathrm{cm}^{3}$, dan $(15 \times 4 \times 0.3) \mathrm{cm}^{3}$, masing-masing ukuran dipotong sebanyak 12 buah pelat. Setelah itu, pelat dibentuk menjadi siku dengan cara di las. Sebelum dilakukan pemasangan pelat besi, dilakukan pengeboran terlebih dahulu pada pelat tersebut untuk mempermudah pemasangan sekrup yang dijadikan sebagai penguat pelat besi pada sambungan kayu dan digunakan sebanyak dua buah sekrup pada masing-masing sisi pelat besi. Pemasangan pelat siku besi dilakukan dengan meletakkan pelat tersebut di sambungan siku bagian dalam seperti yang disajikan pada Gambar 2.

Pengujian sifat fisis meliputi kadar air, kerapatan, dan berat jenis. Contoh uji sifat fisis kerapatan, berat jenis, dan kadar air digunakan ukuran $(2 \times 2 \times 2) \mathrm{cm}^{3}$ berdasarkan standar British Standard (BS-373-1957). Contoh uji ditimbang berat awalnya dan diukur dimensinya lalu dikeringkan dalam oven pada suhu $(103 \mathrm{ffl} 2){ }^{\circ} \mathrm{C}$ selama $2 \times 24$ jam, kemudian ditimbang berat kering ovennya dan diukur kembali dimensinya.

Pengujian MOE dan MOR mengacu pada standar American Society Testing Method (ASTM) D143-03 menggunakan Universal Testing Machine merk Instron kapasitas 5 ton. Contoh uji yang digunakan berukuran $2.5 \mathrm{~cm}$ x $2.5 \mathrm{~cm}$ x $41 \mathrm{~cm}$ dengan jarak sangga $36 \mathrm{~cm}$ dan kecepatan pembebanan $1.3 \mathrm{~mm} /$ menit. Nilai MOE dihitung dengan persamaan sebagai berikut:

$$
\operatorname{MOE}\left(\mathrm{kg} / \mathrm{cm}^{2}\right)=\frac{\Delta P L^{3}}{4 \Delta \mathrm{Ybh}^{3}} \quad \text { dan } \quad \operatorname{MOR}\left(\mathrm{kg} / \mathrm{cm}^{2}\right)=\frac{3 P m L}{2 b h^{2}}
$$

Dimana: MOE $=$ modulus elastisitas $\left(\mathrm{kg} \cdot \mathrm{cm}^{-2}\right) ; \mathrm{MOR}=$ modulus patah $\left(\mathrm{kg} \cdot \mathrm{cm}^{-2}\right) ; \mathrm{Pm}=$ beban maksimum $(\mathrm{kg}) ; \mathrm{L}=$ jarak sangga $(\mathrm{cm}) ; \Delta \mathrm{P}=$ beban sebelum batas proporsi $(\mathrm{kg}) ; \Delta \mathrm{Y}$ = besarnya perubahan defleksi akibat perubahan beban $\mathrm{P}(\mathrm{cm}) ; \mathrm{b}=$ lebar contoh uji $(\mathrm{cm})$; dan $\mathrm{h}=$ tebal contoh uji $(\mathrm{cm})$. 


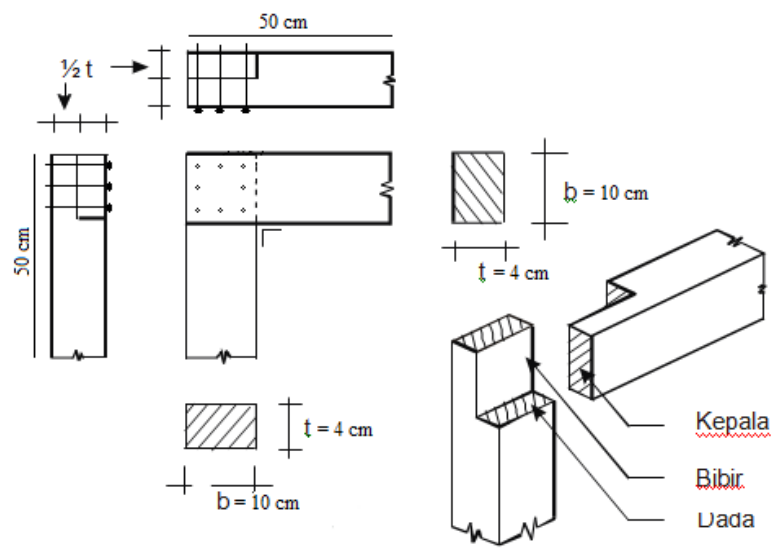

Gambar 1. Desain pembuatan sambungan takikan lurus

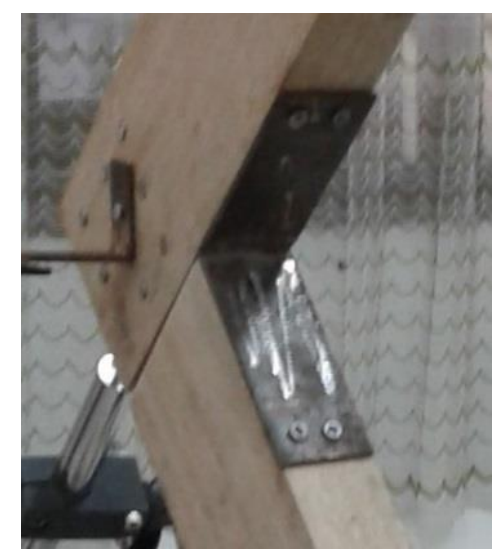

Gambar 2. Pelat besi pada sambungan takikan lurus

Pengujian kuat lentur paku dilakukan untuk mengetahui kekuatan lentur pada paku sebagai pengencang sambungan. Pengujian kuat lentur paku dilakukan dengan mengacu pada ASTM F1575-03. Nilai kekuatan lentur paku dihitung dengan persamaan sebagai berikut:

$$
F_{y b}=\frac{M_{y}}{S}=\frac{\frac{P \times S_{b p}}{4}}{\frac{d^{3}}{4}}
$$

Dimana : $\mathrm{F}_{\mathrm{yb}}=$ Kuat lentur paku $\left(\mathrm{kg} \cdot \mathrm{cm}^{-2}\right) ; \mathrm{S}=$ Efektif bagian plastik modulus untuk sendi plastis penuh (untuk melingkar, paku prismatik, $\mathrm{S}=\mathrm{D}^{3} / 4$, dimana $\mathrm{D}=\operatorname{diameter}$ paku) $(\mathrm{cm})$; $\mathrm{P}=$ Beban uji yang ditentukan dari kurva beban-deformasi $(\mathrm{kg}) ; \mathrm{S}_{\mathrm{bp}}=\operatorname{Jarak}$ titik tumpu $(\mathrm{cm})$; dan $\mathrm{M}_{\mathrm{y}}=$ Dihitung saat berdasarkan beban uji (kg.cm) yaitu sama dengan $\frac{P \times S_{b p}}{4}$.

Pengujian kuat tumpu paku dilakukan untuk mengetahui kekuatan lentur pada paku sebagai pengencang sambungan. Nilai kuat tumpu kayu mengacu pada SNI 7973: 2013 dan dihitung dengan persamaan sebagai berikut:

$$
F e m=F e s=100 \times G^{1,84}
$$

Dimana : Fem = Kuat tumpu utama (kg); Fes = Kuat tumpu sekunder (kg); dan G = Berat Jenis. 
Desain acuan sambungan kayu ditentukan dengan mengacu pada SNI 7973: 2013 mengenai Spesifikasi Desain untuk Konstruksi Kayu. Nilai acuan sambungan kayu ditentukan pada persamaan berikut ini:

$$
\begin{array}{ll}
\text { Im } \quad: Z=\frac{D \times l_{m} \times F_{e m}}{R_{d}} & \\
\text { Is } \quad: Z=\frac{D \times l_{s} \times F_{e s}}{R_{d}} & \quad ; k_{1}=\frac{\sqrt{R_{e}+2 R_{e}\left(1+R_{t}+R t^{2}\right)+R t^{2} R e^{3}}-R_{e}\left(1+R_{t}\right)}{\left(1+R_{e}\right)} \\
\text { II } \quad: Z=\frac{k_{1} \times D \times l_{s} \times F_{e s}}{R_{d}} \quad ; k_{2}=-1+\sqrt{2\left(1+R_{e}\right)+\frac{2 F y b\left(1+2 R_{e}\right) D^{2}}{3 F_{e m} l_{m}^{2}}} \\
\text { IIIm } \quad: Z=\frac{k_{2} \times D \times l_{s} \times F_{e m}}{\left(1+2 R_{e}\right) R_{d}} \\
\text { IIIs } \quad: Z=\frac{k_{3} \times D \times l_{s} \times F_{e m}}{\left(2+R_{e}\right) R_{d}} \quad ; k_{3}=-1+\sqrt{\frac{2\left(1+R_{e}\right)}{R_{e}}+\frac{2 F y b\left(2+R_{e}\right) D^{2}}{3 F_{e m} l_{s}^{2}}} \\
\text { IV } \quad: Z=\frac{D^{2}}{R_{d}} \sqrt{\frac{2 \times F_{e m} \times F_{y b}}{3\left(1+R_{e}\right)}}
\end{array}
$$

Dimana: $\mathrm{D}=$ Diameter $(\mathrm{mm}) ; \mathrm{lm}=$ Panjang tumpu pasak di komponen struktur utama $(\mathrm{mm}) ; \mathrm{ls}=$ Panjang tumpu pasak di komponen struktur sisi $(\mathrm{mm}) ;$ Fem = Kuat tumpu kayu komponen struktur utama (kg); Fes = Kuat tumpu kayu komponen struktur sisi (kg); Rd = Syarat reduksi untuk sambungan pengencang (diameter $\leq 4.318 \mathrm{~mm}$ adalah 2.2 ); $\operatorname{Re}=$ Fem/Fes; Rt = lm/ls; $k_{1}=$ koefisien kekakuan geser acuan dan terkoreksi untuk balok kayu mode II; $\mathrm{k}_{2}$ = koefisien kekakuan geser acuan dan terkoreksi untuk balok kayu mode IIIm; dan $\mathrm{k}_{3}=$ koefisien kekakuan geser acuan dan terkoreksi untuk balok kayu mode IIIs.

Berdasarkan teoristisnya persamaan momen tahanan sambungan ditunjukkan sebagai berikut:

$$
M=4 Z_{1} R_{1}+4 Z_{2} R_{2}
$$

Dimana: $\mathrm{M}=$ Momen tahanan sambungan (kg.cm); $\mathrm{Z}=$ Lateral acuan (kg); $\mathrm{R}_{1}=$ Jarak antar paku (cm); dan $\mathrm{R}_{2}=$ Jarak paku ke titik sumbu pengencang sambungan (cm).

Persamaan momen tahanan sambungan aktual sebagai berikut:

$$
M=P \cdot x
$$

Dimana: $\mathrm{M}=$ Momen tahanan sambungan aktual (kg.cm); $\mathrm{P}=$ Beban maksimum sambungan $(\mathrm{cm})$; dan $\mathrm{x}=$ Panjang lengan momen $(\mathrm{cm})$.

Pengujian tekan sambungan kayu dilakukan untuk mengetahui kekuatan sambungan yang telah diperkuat dengan pelat besi. Sambungan rangka kayu ini diuji menggunakan UTM (Universal Testing Machine) Instron. Sampel sambungan yang digunakan berukuran $10 \mathrm{~cm}$ x $4 \mathrm{~cm}$ x $50 \mathrm{~cm}$ dengan kecepatan pembebanan $3 \mathrm{~mm} /$ menit. Pengujian tekan sambungan kayu ditunjukkan seperti pada Gambar 3. 


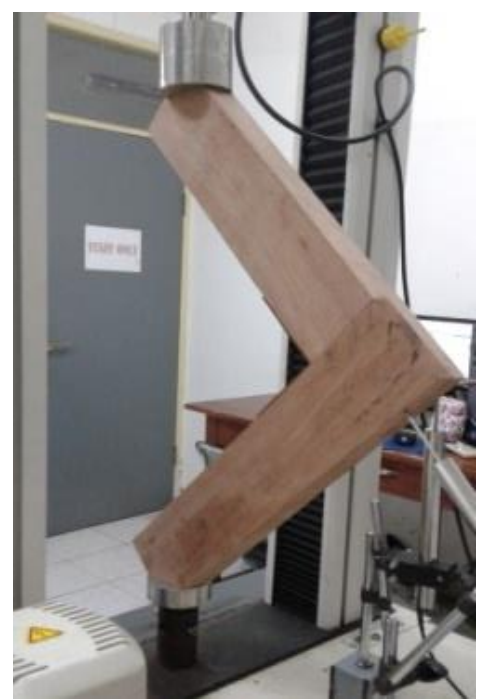

Gambar 3. Pengujian tekan sambungan kayu

Data yang diperoleh kemudian diolah dengan statistika deskriptif dan analisis keragaman menggunakan rancangan acak lengkap. Apabila uji analisis keragaman pada taraf $5 \%$ menunjukkan hasil yang berpengaruh nyata, maka dilakukan uji lanjut Duncan. Aplikasi pengolah data yang digunakan yaitu software Microsoft Excel 2010 dan SPSS 22.0.

\section{HASIL DAN PEMBAHASAN}

\subsection{Sifat Fisis Material Kayu}

Tabel 1 menyajikan sifat fisis dari material kayu yang digunakan dalam penelitian ini. Dari hasil perhitungan rata-rata kadar air tertinggi kayu Kamper terdapat pada balok A sebesar $15.19 \%$ dan terendah pada balok Balok B sebesar $12.58 \%$. Sedangkan, rata-rata tertinggi kayu Mersawa terdapat pada balok A sebesar $15.09 \%$ dan terendah pada balok D sebesar 11.95\%. Hasil penelitian menunjukkan bahwa kadar air dari kedua kayu tersebut telah mencapai kadar air di bawah titik jenuh serat (30\%) dan telah mencapai kadar air kering udara yang secara teoritis berkisar 5-20\%. Kondisi kadar air kedua kayu tersebut menjadikan kekuatan kayu semakin meningkat. Menurut Damanik (2005), saat air dikeluarkan dari dinding sel, molekul-molekul berantai panjang bergerak saling mendekat dan menjadi terikat lebih kuat.

Tabel 1. Nilai rata-rata sifat fisis kayu Kamper dan Mersawa

\begin{tabular}{|c|c|c|c|c|c|c|}
\hline \multirow{3}{*}{ Tipe Balok } & \multicolumn{5}{|c|}{ Jenis Kayu } & \\
\hline & \multicolumn{3}{|l|}{ Kamper } & \multicolumn{3}{|c|}{ Mersawa } \\
\hline & KA (\%) & BJ & $\rho\left(\right.$ g.cm $\left.{ }^{-3}\right)$ & $\mathrm{KA}(\%)$ & BJ & $\boldsymbol{\rho}\left(\right.$ g.cm $\left.\mathrm{cm}^{-3}\right)$ \\
\hline Balok A & 15.19 & 0.69 & 0.79 & 15.09 & 0.54 & 0.61 \\
\hline Balok B & 12.58 & 0.75 & 0.84 & 12.19 & 0.62 & 0.69 \\
\hline Balok C & 13.05 & 0.61 & 0.69 & 12.28 & 0.53 & 0.59 \\
\hline Balok D & 13.04 & 0.71 & 0.79 & 11.95 & 0.49 & 0.55 \\
\hline
\end{tabular}

Keterangan:

Balok A : Balok untuk sambungan takikan lurus (kontrol)

Balok B : Balok untuk sambungan dengan perkuatan pelat besi panjang $5 \mathrm{~cm}$

Balok C : Balok untuk sambungan dengan perkuatan pelat besi panjang $10 \mathrm{~cm}$

Balok D : Balok untuk sambungan dengan perkuatan pelat besi panjang $15 \mathrm{~cm}$ 
$\mathrm{KA}=$ Kadar air; BJ = Berat Jenis; dan $\rho=$ Kerapatan.

Nilai rata-rata kerapatan tertinggi yaitu pada balok B kayu Kamper sebesar 0.84 g.cm ${ }^{-3}$ dengan berat jenis 0.75 dan terendah pada balok D kayu Mersawa 0.55 g. $\mathrm{cm}^{-3}$ dengan berat jenis 0.49. Menurut Sadiyo et al. (2012), berat jenis dan/atau kerapatan kayu merupakan salah faktor untuk mengetahui kekuatan dan ketahanan kayu dalam menerima beban atau gaya dari luar. Berdasarkan sifat anatomi kayu, kayu dengan berat jenis yang tinggi memiliki dinding sel yang tebal, dinding sel yang tebal dapat meningkatkan kekuatan kayu. Menurut Bowyer et al. (2003) menyatakan bahwa kekakuan dan kekuatan kayu meningkat dengan meningkatnya berat jenis pada kondisi kayu bebas cacat.

\subsection{Kekuatan Lentur Paku}

Kekuatan leleh lentur paku $\left(\mathrm{F}_{\mathrm{yb}}\right)$ ditentukan dengan metode offset $5 \%$ diameter (0.05D) dari kurva beban - peralihan yang diperoleh dari uji lentur paku (SNI 7973: 2013). Menurut Handayani (2011), kuat lentur paku dapat mempengaruhi tahanan lateral sambungan degan alat sambung paku. Pada pengujian kuat lentur paku diperoleh rata-rata beban leleh paku sebesar $33.4 \mathrm{~kg}$ dengan kekuatan lentur paku sebesar $5369.084 \mathrm{~kg} \cdot \mathrm{cm}^{-2}$. Nilai ini lebih kecil dari nilai kuat lentur paku klasifikasi diamater paku $\leq 3.6 \mathrm{~mm}$ sebesar $7036.04 \mathrm{~kg} / \mathrm{cm}^{2}$ pada SNI 7973: 2013. Berdasarkan uji beda nyata pada selang kepercayaan 95\%, jenis kayu tidak berpengaruh nyata terhadap nilai kekuatan lentur paku. Menurut Awaludin (2005) kuat lentur paku dipengaruhi oleh diamter paku. Semakin meningkatnya diameter paku maka semakin menurun kuat lentur paku.

\subsection{Kuat Tumpu Kayu}

Berdasarkan hasil perhitungan nilai kuat tumpu kayu yang mengacu pada SNI 7973: 2013 diperoleh data seperti pada Gambar 4 yang menunjukkan bahwa nilai tertinggi kuat tumpu kayu Kamper terdapat pada balok B sebesar $597.67 \mathrm{~kg} . \mathrm{cm}^{-2}$ dan terendah pada balok C sebesar $415.63 \mathrm{~kg} . \mathrm{cm}^{-2}$. Sedangkan, nilai tertinggi kuat tumpu kayu Mersawa terdapat pada balok B sebesar $421.88 \mathrm{~kg} . \mathrm{cm}^{-2}$ dan terendah pada terendah D sebesar $274.44 \mathrm{~kg} . \mathrm{cm}^{-2}$. Hasil yang diperoleh menunjukkan bahwa kuat tumpu kayu meningkat seiring dengan peningkatan berat jenis. Berdasarkan uji beda nyata pada selang kepercayaan 95\%, jenis kayu tidak berpengaruh nyata pada kuat tumpu kayu. Glisovic et al. (2012) menyatakan bahwa faktor yang berpengaruh pada nilai kuat tumpu adalah berat jenis kayu. Semakin tinggi berat jenis kayu maka semakin besar pula kuat tumpu kayu dan menurut Awaludin (2005), nilai dari kuat tumpu kayu untuk komponen struktur kayu selain ditentukan dari berat jenis, juga ditentukan berdasarkan diameter paku. 


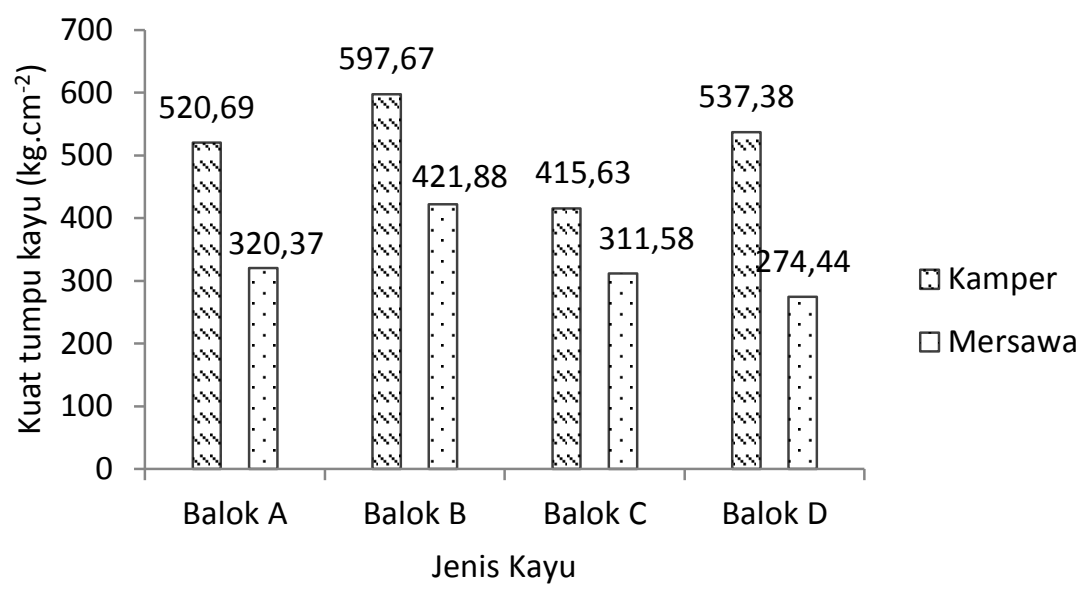

Gambar 4. Nilai kuat tumpu kayu Kamper dan Mersawa

\subsection{Desain Acuan Sambungan Kayu}

Tahanan lateral acuan sambungan $(Z)$ dianalisis berdasarkan mode kelelehan sambungan yang mungkin terjadi (Handayani 2011). Kapasitas sambungan pada masing-masing mode leleh dibatasi oleh kuat tumpu kayu dengan pengencang paku dan kuat lentur paku. Gambar 5 menunjukkan bahwa nilai acuan sambungan tertinggi kayu Kamper terdapat pada sambungan B sebesar $391.20 \mathrm{~kg}$ dan terendah pada sambungan $\mathrm{C}$ sebesar $272.05 \mathrm{~kg}$. Gambar 6 menunjukan nilai acuan sambungan tertinggi kayu Mersawa yaitu pada sambungan B sebesar $276.14 \mathrm{~kg}$ dan terendah pada sambungan D sebesar $179.63 \mathrm{~kg}$. Nilai Z yang dipakai untuk sambungan kayu Kamper dan Mersawa adalah mode I. Menurut Ziannita (2009) Beban pada mode I merupakan beban yang merata karena dalam mekanisme ini alat sambung tidak memutar atau melentur. Kemungkinan dari mode I dapat dibandingkan pada setiap bagian kayu dari sambungan sehingga mode I diklasifikasikan menjadi Mode Im dan Is. Nilai Penentuan nilai desain acuan sambungan pada Gambar 5 merupakan nilai acuan untuk kekuatan sambungan per paku dari sambungan kayu Kamper dan kayu Mersawa. Berdasarkan uji beda nyata pada selang kepercayaan $95 \%$, jenis kayu tidak berpengaruh nyata pada lateral acuan sambungan kayu. Hasil penelitian ini menunjukkan bahwa nilai acuan sambungan kayu meningkat seiring dengan peningkatan kuat tumpu kayu dan berat jenis kayu. Menurut SNI (2013), tahanan lateral acuan sambungan dengan alat pengencang paku ditentukan oleh beberapa faktor seperti kuat lentur paku, kuat tumpu kayu, dan geometri sambungan yang meliputi: diameter alat sambung, ketebalan kayu, serta sudut sambungan.

\subsection{Kapasitas Maksimum Sambungan Kayu}

Berdasarkan uji beda nyata pada selang kepercayaan 95\%, interaksi antara jenis kayu dengan perlakuan perkuatan pelat besi berpengaruh nyata terhadap kapasitas sambungan kayu. Berdasarkan uji lanjut duncan, perlakuan kontrol sambungan menghasilkan nilai yang berbeda terhadap masing-masing perlakuan pelat besi 5,10 , dan $15 \mathrm{~cm}$ serta penggunaan pelat besi $10 \mathrm{~cm}$ dan $15 \mathrm{~cm}$ menghasilkan nilai yang berbeda dengan pelat besi $5 \mathrm{~cm}$. pada setiap jenis kayunya. Hal ini ditunjukkan pada Gambar 7 bahwa nilai kapasitas maksimum sambungan tertinggi kayu Kamper yaitu pada perlakuan perkuatan pelat besi dengan panjang $5 \mathrm{~cm}$ sebesar $435.54 \mathrm{~kg}$ dan terendah pada perlakuan kontrol sebesar $329.03 \mathrm{~kg}$. Sedangkan, kapasitas maksimum sambungan tertinggi kayu Mersawa yaitu pada perlakuan 
pelat besi dengan panjang $15 \mathrm{~cm}$ sebesar $342.22 \mathrm{~kg}$ dan terendah pada perlakuan kontrol sebesar $246.58 \mathrm{~kg}$. Hasil penelitian yang diperoleh menunjukkan bahwa terdapat peningkatan beban sambungan yang signifikan antara perlakuan kontrol sambungan kayu Kamper dengan perkuatan pelat besi panjang $5 \mathrm{~cm}$ dan terjadi penurunan kapasitas sambungan pada perkuatan pelat besi dengan panjang $10 \mathrm{~cm}$ dan $15 \mathrm{~cm}$. Namun, nilai tersebut lebih tinggi dari beban yang diterima pada perlakuan kontrol sambungan kayu Kamper. Sementara pada sambungan kayu Mersawa mengalami peningkatan beban dari perlakuan kontrol sambungan terhadap masing-masing perkuatan pelat besi namun peningkatan beban pada sambungan tidak signifikan. Hal ini diduga dapat disebabkan karena pengaruh beberapa faktor seperti perubahan kadar air dan berat jenis, jumlah sekrup sebagai pengencang pelat besi yang digunakan pada setiap perlakuan dan/atau kekuatan leleh lentur paku. Agussalim (2010) menyatakan bahwa kekuatan sambungan kayu dapat dipengaruhi oleh faktor kekuatan leleh lentur paku. Paku yang memiliki nilai kekuatan lentur yang rendah cenderung merusak kayu sehingga menghasilkan beban yang lebih kecil saat disambung.

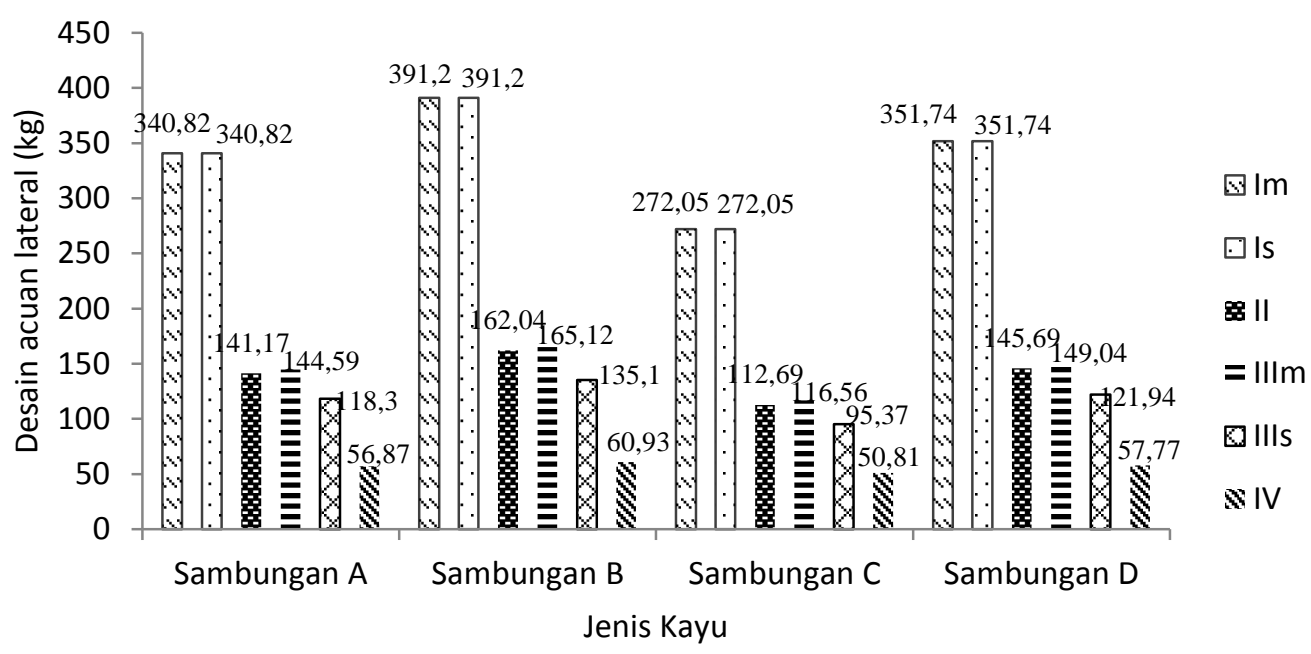

Gambar 5. Desain acuan lateral (Z) sambungan kayu Kamper

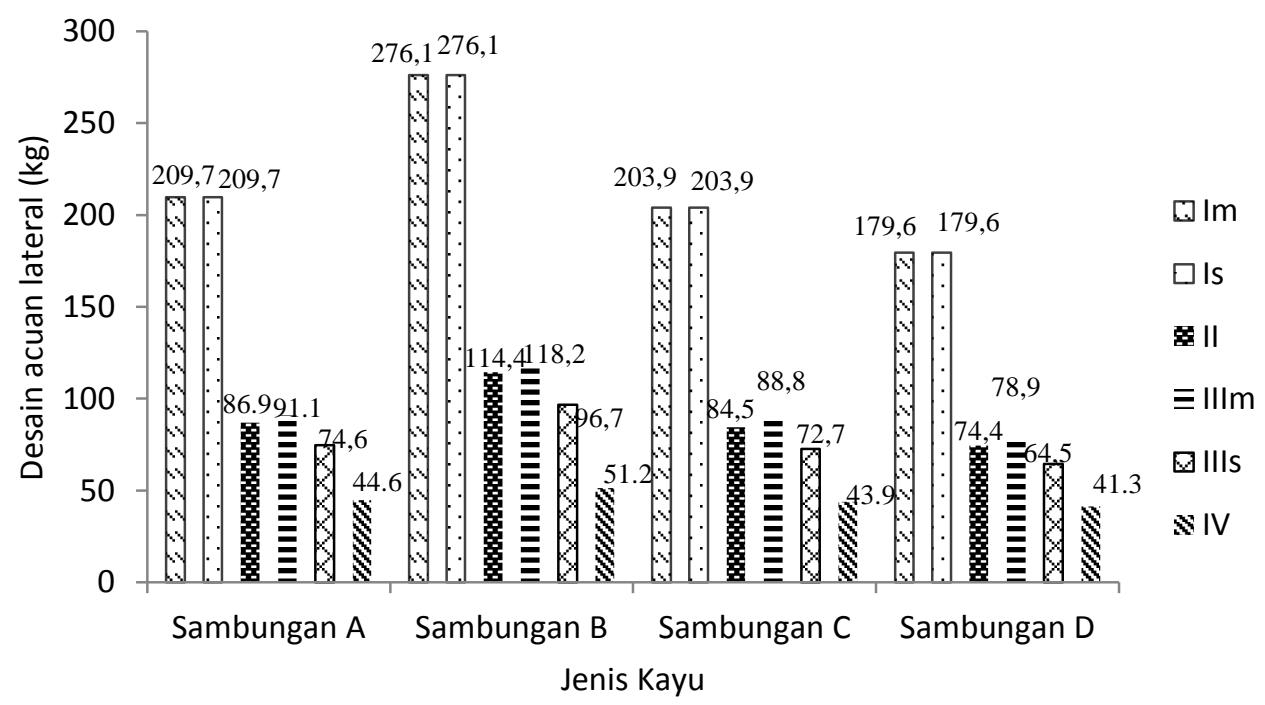

Gambar 6. Desain acuan lateral (Z) sambungan kayu Mersawa 


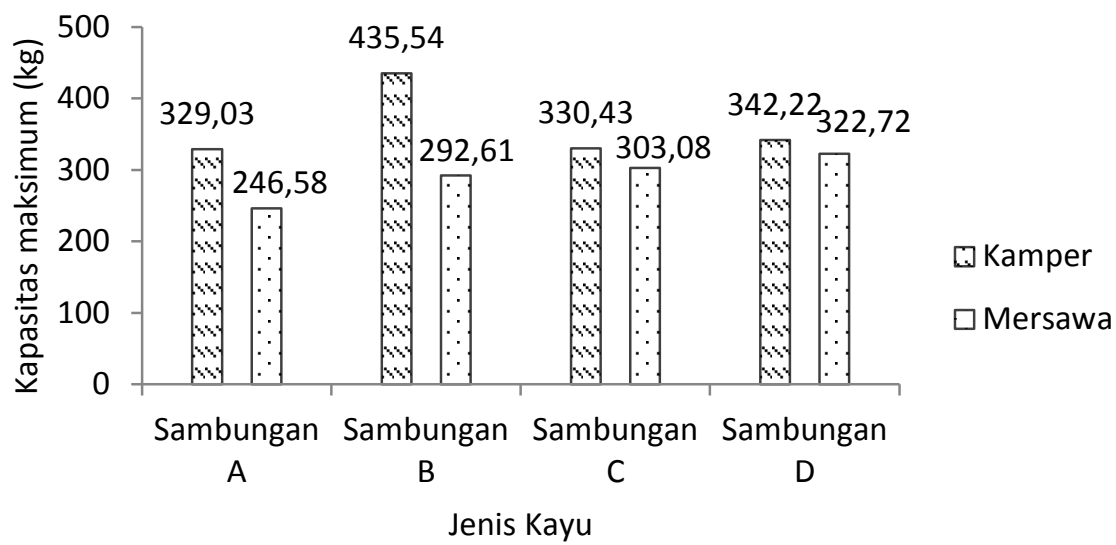

Gambar 7. Nilai rata-rata kapasitas maksimum sambungan kayu Kamper dan Mersawa

\subsection{Momen Tahanan Sambungan Kayu}

Menurut Awaludin et al. (2011), tahanan momen sambungan pada alat pengencang paku diperoleh dari hasil kekuatan lateral sambungan per pakunya dengan jarak alat sambung ke pusat kelompok alat sambung tersebut. Tabel 2 menunjukkan nilai momen tahanan sambungan aktual tertinggi kayu Kamper yaitu pada sambungan B kayu kamper sebesar 15398.49 kg.cm dan terendah pada sambungan A sebesar 11632.86 kg.cm. Sedangkan, nilai tahanan momen sambungan aktua; tertinggi kayu Mersawa yaitu pada sambungan D sebesar $11409.79 \mathrm{~kg} . \mathrm{cm}$ dan terendah pada sambungan A sebesar $8717.93 \mathrm{~kg} . \mathrm{cm}$. Momen tahanan aktual pada sambungan B, C, dan D memiliki peningkatan nilai yang signifikan dibandingkan momen tahanan acuan. Perbedaan nilai momen tahanan tersebut karena adanya perlakuan perkuatan pelat besi pada masing-masing sambungan kayu baik kayu Kamper maupun Mersawa. Berdasarkan uji beda nyata pada selang kepercayaan 95\%, jenis kayu tidak berpengaruh nyata pada momen tahanan sambungan kayu. Tahanan momen sambungan kayu sangat dipengaruhi oleh konfigurasi kelompok alat sambung atau alat pengencang. Sambungan dengan jumlah alat sambung yang sama, tetapi konfigurasi kelompok alat sambung berbeda mengakibatkan nilai tahanan momen yang berbeda (Awaludin 2005).

Tabel 2. Nilai rata-rata momen tahanan sambungan kayu Kamper dan Mersawa

\begin{tabular}{lllll}
\hline \multirow{2}{*}{ Tipe Sambungan } & \multicolumn{3}{c}{ Jenis Kayu } \\
\cline { 2 - 5 } & \multicolumn{1}{c}{$\mathrm{M}_{\text {acuan }}(\mathrm{kg.cm})$} & $\mathrm{M}_{\text {aktual }}(\mathrm{kg.cm})$ & $\begin{array}{c}\mathrm{M}_{\text {acuan }} \\
(\mathrm{kg} . \mathrm{cm})\end{array}$ & $\mathrm{M}_{\text {aktual }}(\mathrm{kg.cm})$ \\
\hline Sambungan A & 9873.65 & 11632.86 & 6075.11 & 8717.93 \\
Sambungan B & 11333.26 & 15398.49 & 7999.94 & 10345.27 \\
Sambungan C & 7881.45 & 11682.57 & 5908.39 & 10715.65 \\
Sambungan D & 10190.06 & 12099.19 & 5203.99 & 11409.79 \\
\hline
\end{tabular}

Keterangan :

$\mathrm{M}_{\text {acuan }}$ : Momen tahanan acuan sambungan kayu

$\mathrm{M}_{\text {aktual }}$ : Momen tahanan aktual sambungan kayu

\subsection{Pola Kerusakan Sambungan Kayu}

Menurut Awaludin (2005), kerusakan pada sambungan dapat berupa pecahnya kayu diantara dua alat sambung, bengkoknya alat sambung, atau lendutan (efek kumulatif dari 
sesaran alat sambung) sudah melampaui nilai toleransi. Dari hasil penelitian yang dilakukan, Gambar 8 menunjukkan pembebanan maksimum sambungan hingga mencapai kerusakan pada area takikan dan sudut pada sambungan kayu berubah sehingga menimbulkan kerusakan pada pelat besi berupa bengkok. Kerusakan pada sambungan kayu yang terjadi berupa pecahnya kayu pada daerah sambungan takikan lurus. Kerusakan yang terjadi termasuk pada mode Im dan Is. Menurut Ziannita (2009), mode Im merupakan model yang memperlihatkan kerusakan pada bagian main member dan mode Is memperlihatkan bahwa terjadi kerusakan pada bagian side member. Saat pembebanan maksimum pengencang sambungan (paku) dan perkuatan pelat besi masih mampu menahan sambungan untuk runtuh, namun pembebanan sudah mulai turun.
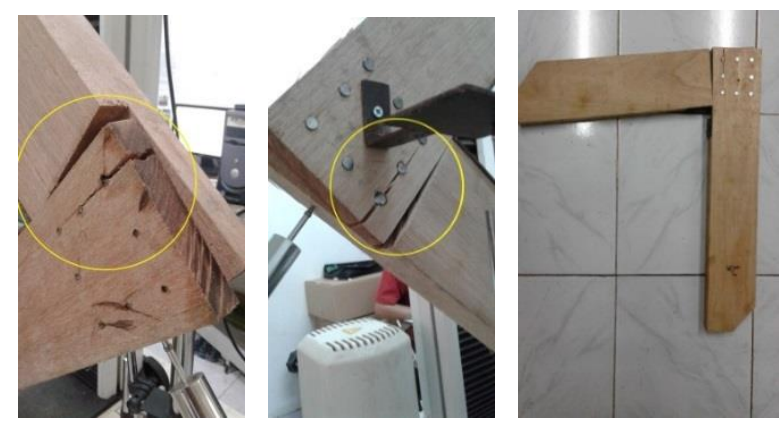

Gambar 8. Kerusakan pada sambungan kayu saat pembebanan maksimum

\section{KESIMPULAN}

Berdasarkan hasil pengujian, penggunaan tambahan pelat besi pada sambungan kayu takikan lurus mampu meningkatkan kapasitas tahanan sambungan tersebut. Hal ini dibuktikan dari nilai momen tahanan aktual sambungan dengan pelat besi yang lebih tinggi dari nilai momen acuan dan momen tahanan sambungan tanpa pelat besi baik pada kayu Kamper maupun Mersawa. Peningkatan ukuran pelat besi cenderung mengurangi kekuatan tahanan momen pada sambungan kayu Kamper. Namun hal ini berbeda pada sambungan kayu Mersawa yang cenderung mengalami peningkatan kapasitas tahanan momen seiring bertambahnya ukuran pelat besi yang digunakan.

\section{DAFTAR KEPUSTAKAAN}

Agussalim. 2010. Desain kekuatan sambungan kayu geser ganda berpelat baja dengan baut pada lima jenis kayu Indonesia [tesis]. Bogor (ID): IPB Pr.

[ASTM] American Society for Testing and Material. 2005. Annual Book of ASTM Standard. Vol. 0410. Wood. D-143-94 (Reapproved 2000): Standard Test Methods for Small Clear Specimens of Timber. USA.

[ASTM] American Society for Testing and Material. 2003. Annual Book of ASTM Standard. Vol. 0301. Wood. F-1575-03 (Reapproved 2002): Standard Test Methods for Determining Bending Yield Moment of Nails. USA.

Awaludin A. 2005. Dasar-dasar Perencanaan Sambungan Kayu. Yogyakarta (ID): UGM Pr.

Awaludin A, Hirai T, Hayashikawa T, Oikawa A, Sasaki Y, Leijten AJM. 2011. Seismic properties of moment-resisting timber joints with a combination of bolts and nails. Civil Engineering Dimension. 13(1): 4.

Bowyer JL, Haygreen JG, Shmulsky R. 2003. Forest Products and Wood Science:An Introduction. Iowa (US): IOWA State University Pr.

[BS] British Standard. 1999. BS 373: 1957. Methods of Testing Small Clear Specimens of Timber. GB. Damanik RIM. 2005. Kekuatan Kayu. Medan (ID): USU Pr.

Danasasmita, Kosasih E. 2004. Struktur Kayu II. Bandung (ID): UPI Pr. 
Glisovic I, Stevanovic B, Kocetov IS. 2012. Embedment test of wood for dowel-type fasteners. Wood Research. 57(4): 639-650.

Handayani ND. 2011. Modulus elastisitas dan kekuatan tekan glued laminated timber(glulam) [tesis]. Bogor (ID): IPB Pr.

Kurniady WR. 2007. Pemanfaatan material bambu sebagai material bangunan sederhana didaerah rawan gempa [skripsi]. Bandung (ID): ITB Pr.

Martawijaya A, Kartasujana I. 1977. Ciri Umum Sifat dan Kegunaan Jenis-jenis Kayu Indonesia. Bogor (ID): Lembaga Penelitian Hasil Hutan.

Onrizal. 2007. Teknik Pengenalan dan Analisis Vegetasi Hutan Mangrove. Affandi O, editor. Medan (ID): USU Pr.

PKKI. 1961. Tata cara perencanaan konstruksi kayu Indonesia (PKKI NI-5). Bandung (ID): Lembaga Penyelidikan Masalah Bangunan, Departemen Pekerjaan Umum dan Tenaga Listrik.

Porteous J, Kermani A. 2007. Structural Timber Design to Eurocode 5. New Jersey (US): Blackwell Publishing.

Tikno I. 2008. Mengenal Konstruksi Kayu untuk Furnitur dan Bangunan. Jakarta (ID): Esensi.

Sadiyo S, Wahyudi I, Yoresta FS, Nurhasanah, Sholihin M. 2012. Nilai desain acuan sambungan kayu geser ganda dengan paku berpelat sisi baja akibat beban uni-aksial tekan menurut berbagai analisis pendekatan. Jurnal Parennial. 6(1): 1-10.

[SNI] Standar Nasional Indonesia. 2012. Spesifikasi desain untuk konstruksi kayu (SNI 7973: 2013). Jakarta (ID): Badan Standardisasi Nasional.

Somayaji S. 1995. Civil Engineering Materials. New Jersey(US): Prentice-Hall.

Supriatna N. 2011. Struktur Baja I. Bandung (ID): UPI Pr.

Surjokusumo S, Bachtiar ET, Nugroho N. 2003. Pemberdayaan Kayu Konstruksi. Dalam: Awaludin A, (editor). Dasar-dasar Perencanaan Sambungan Kayu. Seminar Nasional Teknik Sipil dan Perencanaan, 2007; Jakarta, Indonesia. Yogyakarta (ID): UGM Pr.

Yap F. 1964. Konstruksi Kayu. Bandung (ID): Trimitra Mandiri.

Ziannita V. 2009. Nilai desain acuan sambungan double shear balok kayu-pelat baja empat jenis kayu pada tiga diameter paku menurut berbeagai analisis pendekatan [skripsi]. Bogor (ID): IPB Pr. 


\section{CALL FOR PAPER}

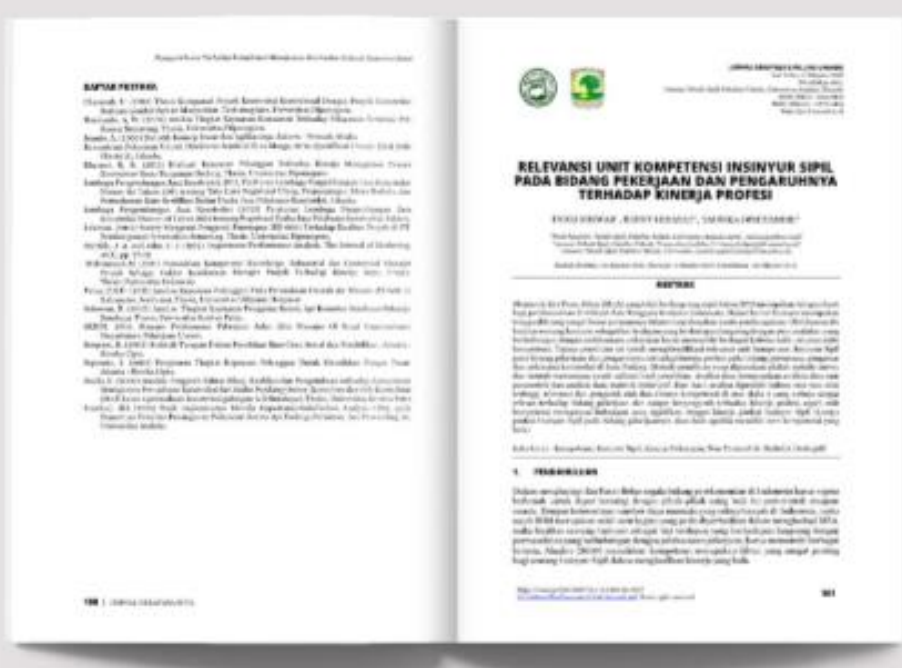

Jurnal Rekayasa Sipil (JRS-Unand)

Edisi 14(2) - Oktober 2018

Info : http://jrs.ft.unand,ac,id 